\title{
Green Fantasies: Photographic representations of biodiversity and ecotourism in the Western Pacific
}

Simon Foale, Australian National University ${ }^{1}$

Martha Macintyre, University of Melbourne ${ }^{2}$

\begin{abstract}
"The photographer is now charging real beasts, beleaguered and too rare to kill. Guns have metamorphosed into cameras in this earnest comedy, the ecological safari, because nature has ceased to be what it always had been - what people needed protection from. Now nature - tamed, endangered, mortal - needs to be protected from people. When we are afraid we shoot. But when we are nostalgic, we take pictures."

Susan Sontag (1977: 15)
\end{abstract}

\section{Introduction}

In his groundbreaking book European Vision and the South Pacific (1959:viii), Bernard Smith proposed that "...in the century preceding the publication of The Origin of Species (1859) the Pacific provided a challenging new experience for Europeans, one which placed unprecedented pressure upon biblical creation theory and provided a wealth of new evidence out of which was fashioned eventually the first scientifically credible theory of evolution". The scientific observations, and especially the drawings and paintings undertaken by botanists, natural historians and artists who went on exploratory expeditions, generated debate, speculation and scientific theories that are now the basis for contemporary interest in the South Pacific environment notably the observation, classification and conservation of its biodiversity.

Smith argued that the artists who attempted to capture the strange exotic beauty of Pacific landscapes, flora, fauna and natural phenomena were consistently inspired, but also constrained by their peculiarly European vision. He demonstrated the ways that artistic genres and cultural values imbued the paintings, drawings and sketches that Europeans brought back from their voyages while simultaneously shaping and distorting the world that they encountered. Crucial to this was what Henrietta Kuklick has characterised as a '...conventional European view' of the subjects of anthropological study as ... 'technologically unsophisticated, preliterate peoples [who] were living in humankind's primeval condition' (1991:1). This perception has persisted and developed permutations that render tribal people, especially those in the Pacific, as both incapable of protecting their natural environment (and therefore in need of assistance from Western environmentalists with a more scientific view) and as 'natural' stewards of its resources (WWF 2003). Either way, the people of the Pacific are perceived and represented entirely in terms of their relationship with an idealised "Nature" - one which must be preserved, and this preservationist

1. Resource Management in Asia-Pacific Program, Dept of Anthropology, RSPAS, Australian National University, ACT 0200, Australia simonjf@bigpond.com. The analyses of nature photography and its relationships to ecology and ecotourism presented in this paper draw in part from Simon Foale's experience as both a marine ecologist, and as a semi-professional photographer whose pictures are regularly used by Lonely Planet Publications for its travel guides and other publications.

2. Centre for the Study of Health and Society, The University of Melbourne, VIC 3010, Australia marthamac@bigpond.com. Martha Macintyre is a social anthropologist with long experience in a number of coastal Melanesian societies, and she has published extensively on many aspects of the complex relationships between rural Melanesians and their coastal resources, including traditional maritime exchange systems, the social and economic impacts of mining, gender and human rights, and other facets of modernity in Melanesia. She is President of the Australian Anthropological Society. 
message is communicated most powerfully through the medium of photography. As Susan Sontag notes (1977: 15-16):

Cameras began duplicating the world at that moment when the human landscape started to undergo a vertiginous rate of change: while an untold number of forms of biological and social life are being destroyed in a brief span of time, a device is available to record what is disappearing.

Nature Photography, particularly as it is used in the service of environmentalist campaigns, has thus produced a partial and romantically-inflected vision of the Pacific that owes more to its cultural origins in the industrial nations of Western Europe and North America (the North or the West) than it does to the experience or cultures of the people of the Pacific. Just as the 18th century paintings of the Pacific by Hodges recreated the region as a site of European aesthetic consumption and scientific inquiry (Thomas 2003:191-194), so nature photography transforms the 'natural' world of Pacific islands and reefs into the virtual reality of a specific contemporary vision that is similarly alien. Sontag's comment on the nostalgic or elegiac role of the camera in capturing images is in some respects modified by the way that environmentalists use photography to serve political ends and reinforce an ideology of moral engagement with 'Nature'. In this paper we examine the ways that the campaigns around the preservation of 'biodiversity' in the Pacific employ images that have an uneasy and inauthentic ${ }^{3}$ relationship with the scientific arguments they are supposed to illuminate. We argue that the use of these images to publicise ecotourism similarly perpetuates a view of the Southwest Pacific as a site of Western consumption, excluding many of the harsh realities of life for local inhabitants and mystifying their relationship to, and understandings of their natural environment.

\section{The scientific and cultural importance of Pacific biodiversity}

The international environmental organisations currently working in the Southwest Pacific and Papua New Guinea without exception focus on policies for the conservation of biodiversity (AKA E.Wilson 1992; N.Myers et al. 2000). Why is biodiversity important and what is threatening it in these countries? The biodiverse ecosystems of concern in the Southwest Pacific are wet tropical rainforests, and coral reefs. Both of these systems are extremely species-rich, indeed most biologists refer to them as megadiverse (J.Veech 2003). This megadiversity is under threat from logging, coastal development, land clearing due to rapidly expanding shifting cultivation, overfishing (particularly destructive fishing such as dynamite fishing), mining, and global warming (R.Goodland et al. 1990; C.Roberts 1993; 1995; O.Hoegh-Guldberg 1999). The goal of conservationists is thus to mitigate these threats somehow, but the fact that the conservation ideology is largely driven by actors from wealthy countries means that they are politically compelled to achieve this goal without significantly compromising the economic returns that these various destructive activities generate for the local people.

The concern about biodiversity is ostensibly informed by biological and ecological science (E.Wilson 1992; G.Orians et al. 1996; M.Loreau et al. 2001), but as Alexej Ghilarov (1996) convincingly argues, since its invention in the late 1980 s, the term biodiversity has taken on a life of its own, and has in fact become politicised and sequestered by a profoundly unscientific narrative, which has been extensively analysed in the writings of James Fairhead and Melissa Leach $(1994 ; 1996 ; 2000)$, among others. This of course is the familiar Western, dualist image of nature as untouched, pristine and separate from (destructive) culture, and in need of protection from it. Biodiversity has become a moral 'good'. This philosophical position is invariably revealed in the choice of photographs used by these organisations in their publicity material. Before discussing the images however, we look first at the two core scientific ideas underpinning the ideology of biodiversity conservation, and how these are perceived by the (indigenous) custodians of that biodiversity in the Southwest Pacific:

1. The first tenet of the biodiversity conservation ideology concerns the interconnectedness of species, and the importance of these interconnections to ecosystem productivity. If too many species are removed from the "system", it becomes less productive, which negatively affects the well being of people who use the "ecosystem services" of that system. Thus, the destruction of

3. sensu West and Carrier 2003.

2

Vol. 122005

Journal of Political Ecology 
many species of corals by global warming (which causes coral bleaching) or blast fishing removes both primary production (C.Wild et al. 2004) and shelter (C.Roberts 1996; H.Kawasaki et al. 2003), and the system is no longer able to support a fish community and therefore a fishery. Complex or highly speciose systems tend to be more resilient to the removal of small numbers of species because of ecological redundancy, i.e. there can be a large degree of ecological overlap among a "guild" of species (B.Walker 1992). For example, the local extinction of the Green Snail (Turbo marmoratus), throughout much of its range in the IndoPacific (M.Yamaguchi 1993), as a result of over-harvesting for the pearl shell trade, is unlikely to have had a significant impact on the ecological functioning of coral reefs, as there are a number of other species that occupy the same ecological niche. On the other hand simpler or relatively species poor (usually temperate) systems tend to be much less resilient to disturbances, and can collapse or transform to another state quite quickly if even one species is removed (B. Walker 1992, P.Kareiva and M.Marvier 2003). Such species are usually referred to as keystone species.

2. A second, equally important but less often articulated idea informing the environmentalistscientific concern for biodiversity is that of the "inherent value of species", which could also be referred to as the "problematisation of extinction" (S.Foale 2001). This idea is underpinned by the concept of geological time and Darwin's theory of evolution. It attributes a value to scientific knowledge about the historical processes that were involved in evolution and attaches a moral obligation - those who comprehend the extraordinary evolutionary trajectory of species should ensure that it is not foreshortened. Thus people should be concerned about extinction because we know that all of the species on earth today are the product of an immensely long evolutionary process, taking millions of years. This makes the rate of species extinctions within the last century look increasingly alarming, especially as humans have been the main agents of destruction. Indeed this phenomenon has for some time been referred to as the "Extinction Crisis" (N.Myers 1993). Notwithstanding the existence of totemic and culturally significant species in many indigenous societies, the inherent value of species is an idea that is generally not embraced by the vast majority of Pacific Islanders, who are the custodians of the highly speciose rainforests and coral reefs that are the focus of environmental concern in the region. Most of these people are Christians (M.Ernst 1994), and have no time for Darwin's (or his successors') ideas, if they are aware of them at all. As such they tend to be, on the whole, unconcerned about extinction, if it does not immediately threaten food security (R.Bulmer 1982; W.Clarke 1993; F.van Helden 1998; 2001; S.Foale 2001).

The importance of the difference between these two assumptions about biodiversity - the ecological linkages on the one hand, and the inherent value of species on the other - is nowhere better illustrated than in the case of turtles. Turtles have existed since the Jurassic period, and have changed little since then, but populations of most species are currently in decline. Some, such as the Leatherback (Dermochelys coriacea) and the Hawksbill (Eretmochelys imbricata), are listed as critically endangered. Leatherback populations are now so small that extinction is imminent [L.Crowder 2000]. Not surprisingly, photographs of turtles, especially Leatherbacks, abound on the brochures, websites and annual reports of all of the major international environmental Non Government Organisations (NGOs) - The World Wide Fund for Nature (WWF) (http:/ /www.panda.org/about wwf/what we do/species/showspecies.cfm?SID=31\&LID=1\&FH=E), Conservation International (CI) (http://www.conservation.org/xp/CIWEB/programs/turtleflagship) and The Nature Conservancy (TNC) (http://nature.org/magazine/fall2002/turtles). Turtles look 'prehistoric' and so proclaim their evolutionary status, inviting donors and subscribers to fulfil their moral obligation towards the preservation of these ancient species (Figure 1). 


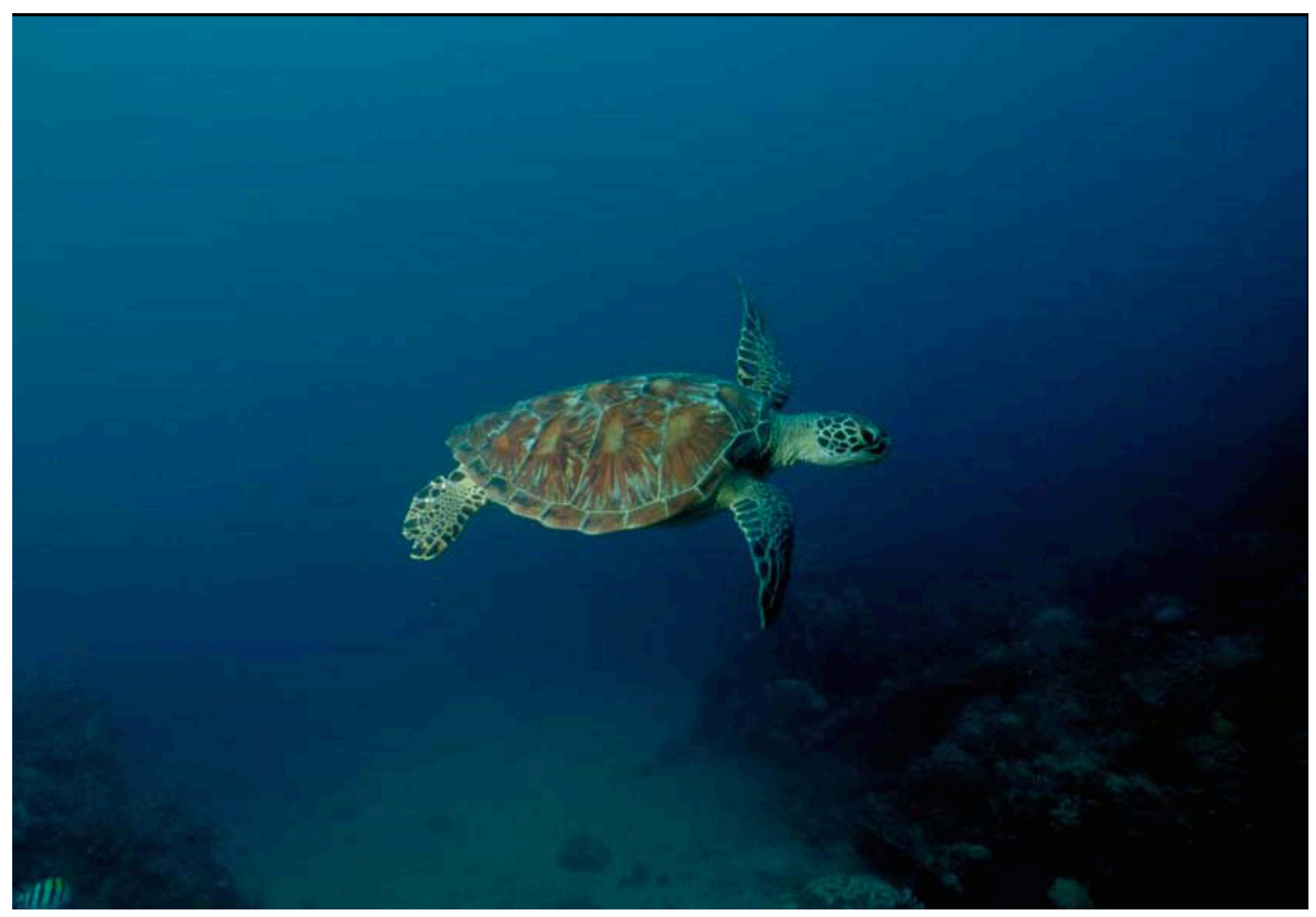

Figure 1. A juvenile Green turtle (Chelonia mydas) swims over a reef in the Solomon Islands.

But the notion of extinction barely impinges on Pacific islanders' engagement with the environment, as for them it is a source of food. Because turtles are relatively rare they are a bonus, and not a staple that must be husbanded - thus their imminent extinction is not a threat to food security in most Pacific communities. There are still plenty of fish on the reefs and yams in the gardens. From the perspective of a Pacific fisherman who happens to catch a large turtle, the removal of a single turtle from the ocean provides an opportunity to feed a group of people and gain prestige by giving away valuable meat. Even when informed that the turtle population is in jeopardy, he is unlikely to be convinced as Pacific islanders generally develop ecological knowledge systems about plant and animal species that are visible, regularly encountered and have some obvious role in subsistence. ${ }^{4}$ When a colleague recently asked a Solomon Islander what he would tell his grandchildren if he knew that he had killed the last Hawksbill turtle on earth, he unabashedly replied that he would tell them how good it tasted (S.Foale 2001).

Will the disappearance of turtles have ecological repercussions throughout Pacific food chains? The following statement from a WWF web page suggests it would:

The marine turtles fill an important ecological role by controlling prey species and themselves providing food to larger predators. The disappearance of marine turtles could therefore have widespread effects in open ocean and coastal ecosystems. (http://www.panda.org/about_wwf/ what_we_do/species/showspecies.cfm?SID=31\&LID=1\&FH=E).

4. This is readily apparent in most folk taxonomies: highly elaborated naming systems typically exist for economically important fauna and flora, while unimportant taxa tend to be lumped (Berlin et al 1973). For example, fishes in the highly speciose families Gobiidae and Blenniidae (J.Randall et al. 1990) tend to be grouped into a handful of categories in most Pacific language taxonomies (S.Foale 1998, A.Pawley 2000). 


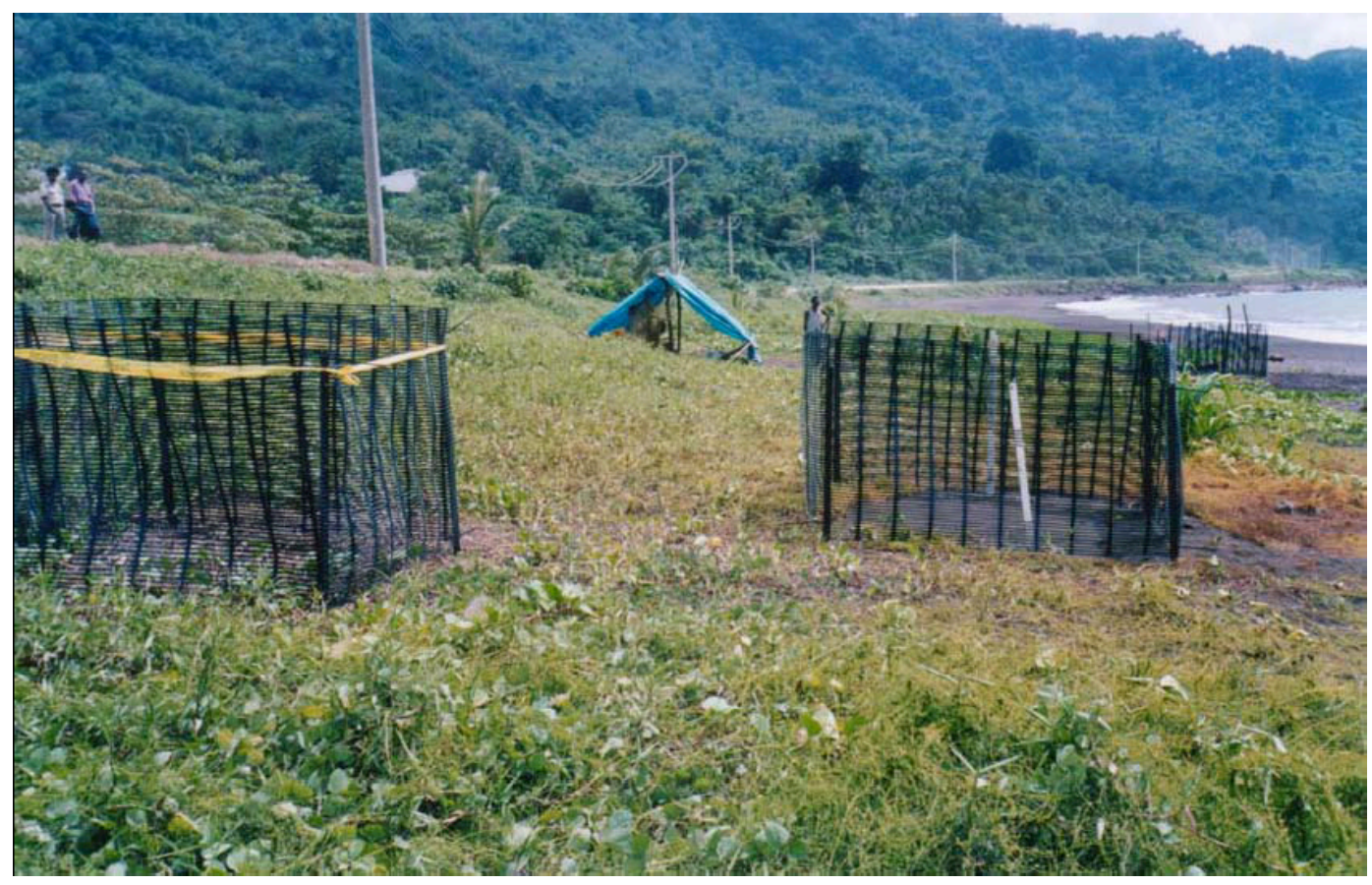

Figure 2. Plastic fences and security guards installed by the Lihir Management Company on a Leatherback turtle (Dermochelys coriacea) nesting beach in order to prevent local villagers from either killing the nesting adults or digging up their eggs.

However this statement is unsubstantiated by ecological evidence. Jeremy Jackson et al. (2001:633-634) have presented a plausible, albeit speculative, argument for the link between declines of Green turtles in the Caribbean and the dieback of seagrass meadows off Florida, and a similar speculation was made by Y.Leon and K.Bjorndal (2002) for Caribbean Hawksbills. But such supposedly inelastic ecological linkages have never been, and in our view are most unlikely to be demonstrated for Pacific Green, Leatherback or Hawksbill turtles. ${ }^{5}$ Turtle photos draw money for conservation of turtles in the Pacific, but the "problem" is externally imposed, just as it

5. For example, floods and cyclones exert a much stronger influence on the relative and absolute abundance of the various species of seagrasses on which both dugongs (Dugong dugon) and green turtles (Chelonia mydas) feed than does grazing by those animals themselves (J.Andre et al. 2005). It is also very unlikely that the disappearance of Hawksbill and Leatherback turtles will result in major trophic cascades generated by population explosions of the organisms that these turtles eat (various coral reef invertebrates in the case of Hawksbills, and oceanic jellyfishes and salps in the case of Leatherbacks). The "delicate ecological balance" between these animals and their environment that is assumed by many environmentalists is a fantasy. This is not to deny the existence of tight trophic linkages between higher vertebrates and their prey in many of the ecologically simpler and less resilient temperate systems - the dramatic trophic cascades that ensue from population fluctuations of Alaskan Sea Otters are a well-documented example (J.Estes and D.Duggins 1995; J. Estes et al. 1998). On the other hand the wholesale depletion of entire guilds of reef fish has resulted in major ecological perturbations in some parts of the Caribbean (N.Knowlton 1992, L.McCook 1999) and the Pacific (N.Dulvy et al. 2004). 
Simon Foale and Martha Mcintyre

was in Kissidougou (J.Fairhead and M.Leach 1996). The result of this is that a mining company in PNG has to put fences around leatherback nests, and pay security guards to protect them from the locals, so that the company can maintain an environmentally friendly image (M.Macintyre and S.Foale 2004b:234) and in the Solomons, at the time of writing, environmentalists are paying locals to allow turtle eggs that they would otherwise have harvested, to hatch on their beaches $-\mathrm{a}$ slight modification of the familiar debt-for-nature paradigm (Figure 2).

\section{Picturing Pristineness}

But there is more to the concern about turtles in our view than just their imminent extinction. Turtles, like pandas, tigers and snowy owls, because of their sheer rareness, are symbolic of pristine unviolated nature - they represent the whole unspoiled system in all its vulnerability. These 'charismatic megafauna' are the species that have retreated furthest from industrial man's presence, and as such, have become all the more precious in the minds of environmentalists. Whether or not they are keystone species, or perform a critical ecosystem service is irrelevant as they evoke a vision of an evolutionary past that is populated by strange amphibian reptiles. They embody our imaginary primeval as it has been made accessible by palaeontologists. As such, photographs (or nature documentaries) of these creatures must convey pristineness and a world devoid of humans. As Seppännen and Väliverronen (2003:59) observe, images of specific 'endangered species' are routinely used as metonyms for biodiversity in newspaper articles, and landscapes of biodiverse 'Nature' are usually portrayed devoid of humans (p66). Derek Bousé corroborates:

When we film lions gorging on a bloody zebra in the Serengeti, or a cheetah flat out after a bounding gazelle, we rarely turn our cameras on the dozen or so Hiace vans and land-rovers, packed with tourists all sharing the wilderness experience. All over the world we frame our pictures as carefully as the directors of costume dramas, to exclude telegraph poles and electricity pylons, cars, roads, and people. No such vestige of reality may impinge on the period-piece fantasy of the natural world we wish to purvey. (D.Bousé 2000:14, cited in L.Vivanco 2002:1196).

The concern for species preservation is imaginatively entwined with the desire for the maintenance of an unspoiled paradise, somewhere that the Westerner can come to escape from industrial bleakness and drudgery. Therefore, the purported ecological importance of the illustrated subject (and we discuss this further in a later section) is used to occlude what is in reality the exploitation of the audience's desire to be tourists, to 'explore', 'discover' and penetrate unviolated nature, to play out the old imperialist fantasy. Henrietta Kuklick demonstrated the way that nineteenth-century ethnological museums were similarly 'educative' and '...intended to provide experiences especially illuminating to the newly leisured and newly enfranchised artisan and lower middle classes.' (1991:108). The political reading of a racial and social hierarchy that she discerns in the ways that museum displays were designed has its contemporary counterpart in the documentary nature film (L.Vivanco 2002), the large format books of photographs and the actual experience of travelling to tropical islands and witnessing the natural environment first hand. Eco-tourism is often viewed as a morally responsible form of recreational travel (because it does not entail the environmental and socio-economic impact that tourism to commercial resorts generates) and it is educational, raising awareness of the biodiversity and promoting environmentalism (H.Ceballos Lascurain 1996). This is why the idea of ecotourism is so emotionally compelling to environmentalists working in the Pacific - it affirms an antimonous view of the Man/Nature divide and provides a moral justification - the protection of an innocent, 'untouched' world.

\section{Ecotourism and the European Vision}

Development in PNG and the Southwest Pacific to date has taken the form primarily of extractive primary industries - logging, mining and industrial fishing. Most of these operations are owned and controlled by foreigners, and a small fraction of the revenue from them flows to landowners and local governments in the form of rent, royalties and taxes. All of these industries 
are environmentally destructive in some way, and environmentalists concerned about mitigating their impacts were faced with the challenge in the 1990s of finding some alternative form of development that was environmentally benign but also generated significant levels of revenue, ideally commensurate with what people were receiving from the industrial developers. This approach took the form of the Integrated Conservation and Development Project (ICAD), and the 1990s saw a proliferation of these all over the world, and there were many in PNG and the Southwest Pacific (F.van Helden 1998:1; 2001; S.Foale 2001; P.West 2000). These projects invariably tried ecotourism as one of the alternative development options (J.-A.Ellis 1997, West and Carrier 2003). Ecotourism projects in the Pacific are designed for low-budget, low-impact travellers, usually back-packers. The guests sleep in traditional leaf houses, eat simple food prepared by local villagers, the toilets are not salubrious, and there is usually no air-conditioning or hot water. The lodges are usually owned and operated by families, or more rarely by communities. The number of guests and the financial turnover is typically very small (E.Hviding and T.Bayliss-Smith 2000:316-317).

By contrast, foreign-owned tourism businesses, such as the live-aboard dive boat operations which are also offered as 'eco-tourism' - afford a much higher level of comfort, and have much higher overheads, and of course, charges. The scale of investment, and management demands, seem to keep these kinds of operations well out of reach of local entrepreneurs. ${ }^{6}$ In fact almost all dive operators in Melanesia are expatriates. A small fraction of the takings flows to locals through employment as skippers or deck hands, rent to reef owners, and purchase of fresh fruit and vegetables.

While the foreign-owned live-aboard dive operations are still operating in PNG and Solomon Islands, all of the ICAD projects, and most of the associated eco-tourism businesses have failed, mainly because they simply could not generate profits that were remotely comparable to the cash payments that were given in the context of competing extractive industrial options (See F.van Helden 1998:6 and C.Filer 1998:43-46). In 2000, the WWF-supported eco-lodge in Western Solomon Islands, Vanua Rapita, yielded a grand total of US\$40 per person for the small community that owned and managed it. By contrast, standard compensation payment for destruction of a single tree in the context of a mining project in Papua New Guinea is in the vicinity of US\$30 (Schedule of Payments for Lihir 1994. Department of Minerals and Energy, PNG). For a community that leases land and loses all use of its forest resources over the designated area, the amounts of compensation can be hundreds of thousands of dollars. That same community might include people who gain employment from the enterprise and so earn wages that enable them to participate in the cash economy and abandon subsistence agriculture - to be active agents and beneficiaries of 'development'. Moreover, the Mining Agreement requires that land cleared around the pit has topsoil restored and is revegetated, thereby reducing long-term environmental impact.

Environmentalists have predictably underestimated the strength of local aspirations for development (c.f. S.Foale 2001; E.Hviding 2003; M.Macintyre and S.Foale 2004a;b), driven primarily by the desire for the affluent lifestyle of the foreigners whom they encounter, whether in person or through various mass media, a desire that is fanned by every contact with rich, cameratoting tourists. This desire is articulated most commonly through requests (to development agencies or in negotiations with mining or logging companies) for permanent houses, water tanks, and money for school fees and medicines (M.Macintyre and S.Foale 2004a; E.Hviding 2003). People are clearly not satisfied with living in the quaint sago leaf and bamboo houses that tourists find so charming. The fact that many ecotourism projects in Melanesia simply fail to deliver the incomes that people aspire to is a problem. But as West and Carrier (2004) demonstrate, using Jamaican and Papua New Guinea examples, such projects also serve to entrench neoliberalist ideas of economic exploitation and subtly establish its institutions in the guise of 'responsible tourism'. They elucidate the contradiction inherent in the tourism as a Western activity and '... its tendency to lead not to the preservation of valued ecosystems but to the creation of landscapes that conform to important Western idealizations of nature through a market-oriented nature politics...'

6. For detailed analyses, from both sides of the political spectrum, of the problems besetting capitalist enterprise in the Western Pacific, see (from the Right) T.Levantis (2000) and H.Hughes (2003, 2004), and (from the Left) R.Gerritson and M.Macintyre (1991) and G.Curry (1999). 
Simon Foale and Martha Mcintyre

(2004:485)

Despite the failures and contradictions, many environmentalists still cling to eco-tourism as the solution to the problem of 'development' without environmental destruction (e.g. http:/ /www.conservation.org/xp/CIWEB/programs/ecotourism/), and it is increasingly clear that their motivation is deeply rooted in the 'European vision' of the Pacific. As Amanda Stronza observes, 'For over a decade ecotourism has played on our hopes and imaginations as a more progressive approach to development, a strategy that purports to meet people's needs while also protecting nature (however defined), delivering a "sustainable" future replete with intact ecosystems, strong local traditions, and robust economies.'(A.Stronza, comment appended to P.West and J.Carrier 2003:492). Eco-tourism is in many respects a way of maintaining a relationship with the South Pacific that constructs it entirely as a commodified cultural entity - a primordial "Nature" to be aesthetically consumed (for an analogous treatment of Madagascar see http:/ /www.conservation.org/xp/madagascar). The environment is valued as "Wilderness", epitomising a domain which the European can enter (with cameras), walk lightly through its rainforest, laze on its white sand beaches, dive on its coral reefs and leave with images of pristine beauty. This encounter with nature and its primeval beauty is a form of recreation - an escape from the industrialised world of the North and an engagement with a prelapsarian appreciation of the abundance of Nature. Perhaps this is another reason why the local human inhabitants are rarely portrayed toiling in gardens or carrying backbreaking loads of food, water and firewood (Figures 3 and 4), or cutting down rainforest trees for timber with which to build houses (Figure 5) - the fantasy of superabundant food obtained with little effort and the illusion that the lives of people are 'simple' and 'easy' are sustained by removing them from the picture, or including them only when they enhance the image of decorative, natural simplicity (e.g.

http://www.conservation.org/xp/CIWEB/regions/asia/melanesia.xml,

http://www.nature.org/wherewework/asiapacific/solomonislands/,

http://www.nature.org/wherewework/asiapacific/papuanewguinea/).

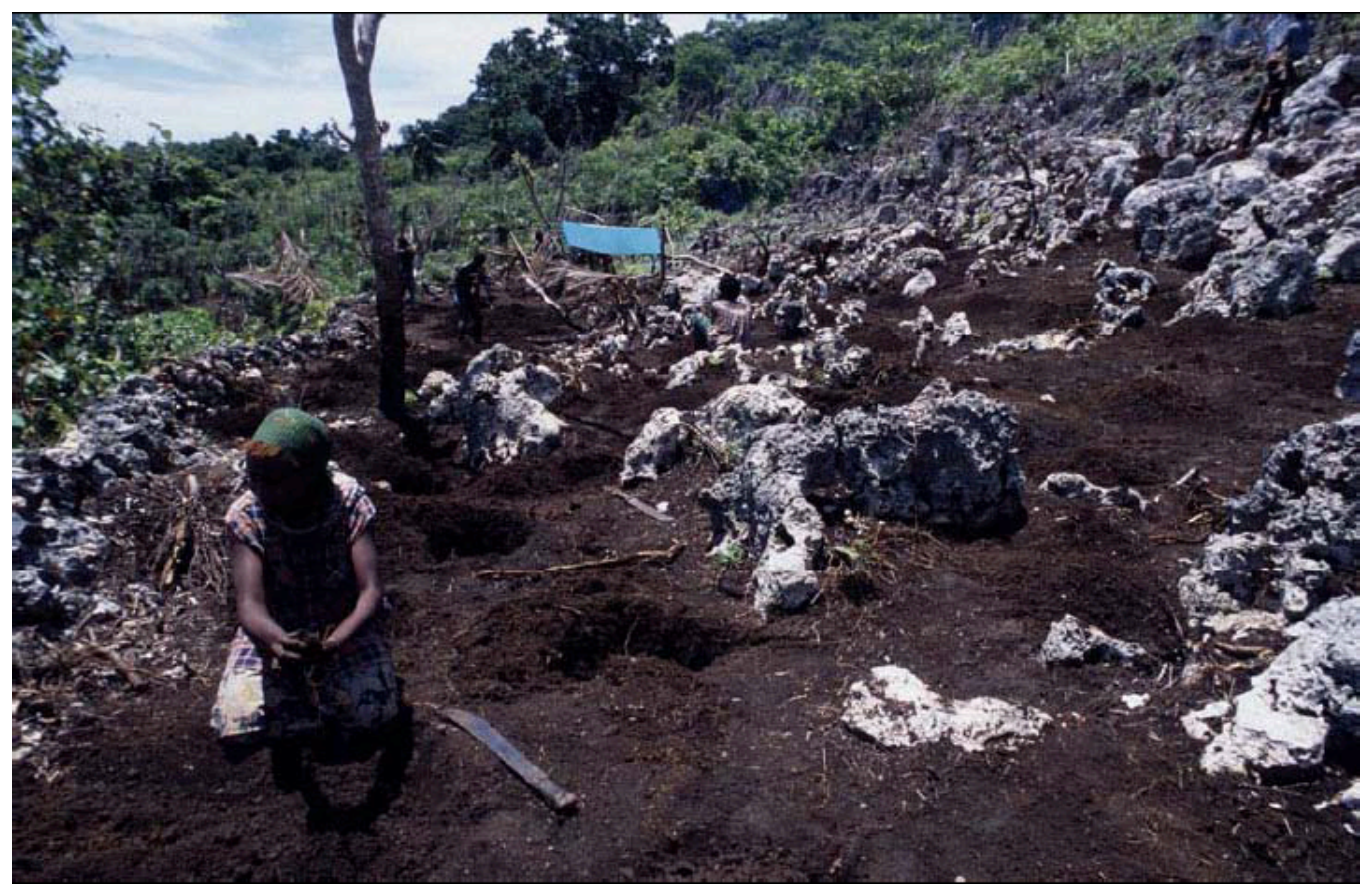

Figure 3. A woman prepares the soil for yam planting on Masahet Island in the Lihir Group, PNG. Subsistence farming in most parts of the Western Pacific is highly labour-intensive, with most of the work done by women. It is rarely observed by tourists, since subsistence gardens are mostly located some distance inland, well away from the beaches and coral reefs which are the main focus of tourist attention. 
The environment of the Pacific is thus constructed as something to be preserved, protected from exploitation and the ravages of industrialisation in order to sustain the ideal of a place where human interaction with Nature is mild, gentle and harmonious. It is essentially desired as a Westerner's Nature playground and the harsh realities of life for many Pacific islanders - poverty, low life expectancy and endemic malaria - are ignored. The cloistered environment of the liveaboard dive boat, protected by the sea from all but the briefest, and usually highly choreographed, contact with the locals, helps to sustain this blinkered view.

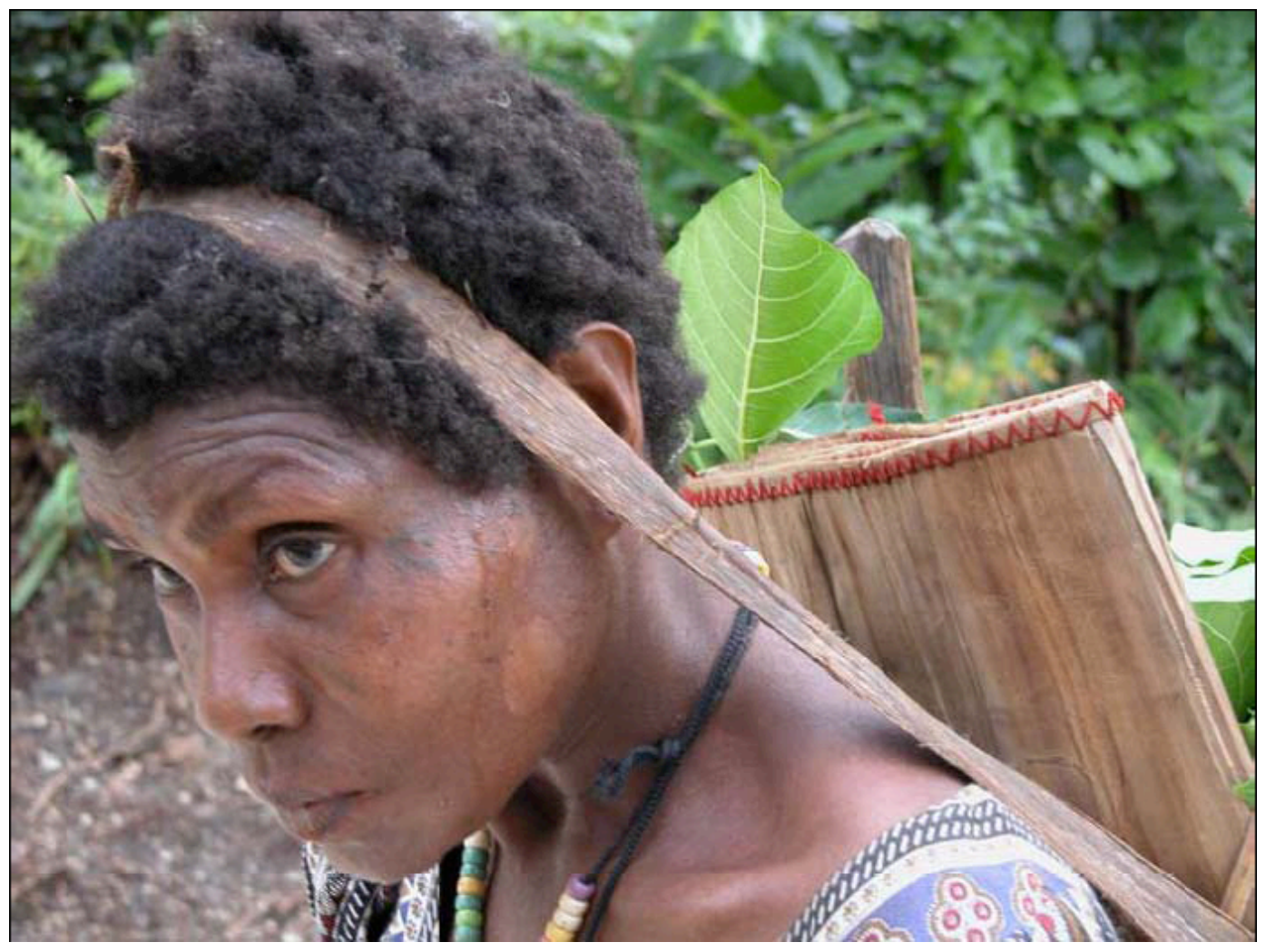

Figure 4. A Lihirian woman carrying a heavy load of yams and firewood. Melanesian women routinely carry loads in excess of $25 \mathrm{~kg}$ long distances between subsistence gardens and their villages. Many have compressed upper vertebral discs by the time they are in their 30s as a result.

Travel guidebooks for the South Pacific, for example Lonely Planet's Solomon Islands (M.Honan and D.Harcomb 1997), and South Pacific: Polynesia, Melanesia and Micronesia (E.Hunt et al. 2000) often use nature photography to present the attractions of tourism destinations. The selection of images for publication is primarily aesthetic, as there is an emphasis on vivid colour, abstract pattern and clarity of composition. The recent coffee-table volume, One Planet: See it for yourself (Lonely Planet, 2003) includes numerous photographs of animals that conform to the 'classic' aesthetic genre. Where people are depicted, they are shown semi-naked or in 'traditional' attire. The jeans and tattered t-shirts that constitute the clothing of choice of young Melanesian men, or the ubiquitous 'meri-blouse' (an enveloping smock introduced by missionaries that is now undeniably the 'national dress' of the region) are eschewed by editors or 
publishers who 'know what the consumers want'.

Nature photography and the photographic advertisements used by ecotourism promoters, for example of diving tours, are often indistinguishable. The genre is the 'aesthetic nature photograph' (e.g. http://www.tourismwestnewbritain.org.pg/Diving.htm, http://www.bilikiki.com/gallery.php).

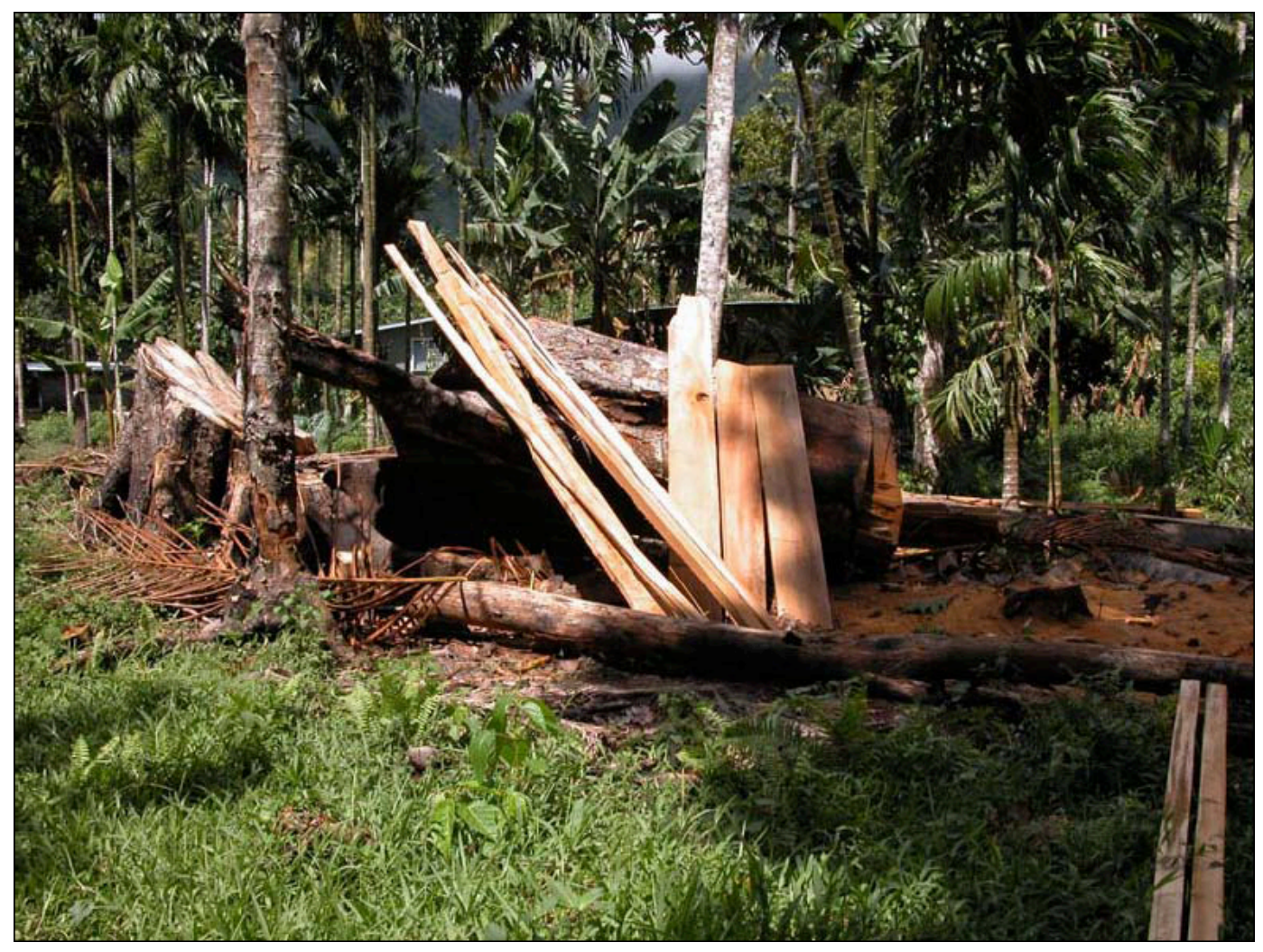

Figure 5. A recently felled and partly sawn breadfruit tree on Niolam Island (Lihir Group), the beams from which will be used as structural timbers in the construction of a local house.

Thus the photograph of a pygmy seahorse (Hippocampus bargibanti) clinging to a gorgonian coral against a flat black background - the classic scientific specimen image - can simultaneously serve to document the discovery of this minute $(9 \mathrm{~mm}$.) animal whose appearance perfectly proclaims its adaptation to a unique ecological niche (e.g. R.Steene 1998:138; Figure 6a) and invite divers to 'See exotic, rare marine life at play in one of the most amazing U/W habitats in the world' (Ocean Realm Winter 2000/1:2 - advertisement for diving tour in Milne Bay Province PNG - Figure 6b). Moreover, the allure of diving ecotourism is in itself to enable the tourist to 'discover' and photograph the pygmy seahorse. Photography thus provides the beginning and the end of the activity, merging the scientific, aesthetic, recreational and representational.

7. Simon Foale's images selected for publication in the guidebooks for Solomon Islands (1997), South Pacific (2000) and One Planet (2004), do not reflect the range of his photographic oeuvre; they are indicative of the style of photograph that 'sells' and perpetuates Western fantasies. 


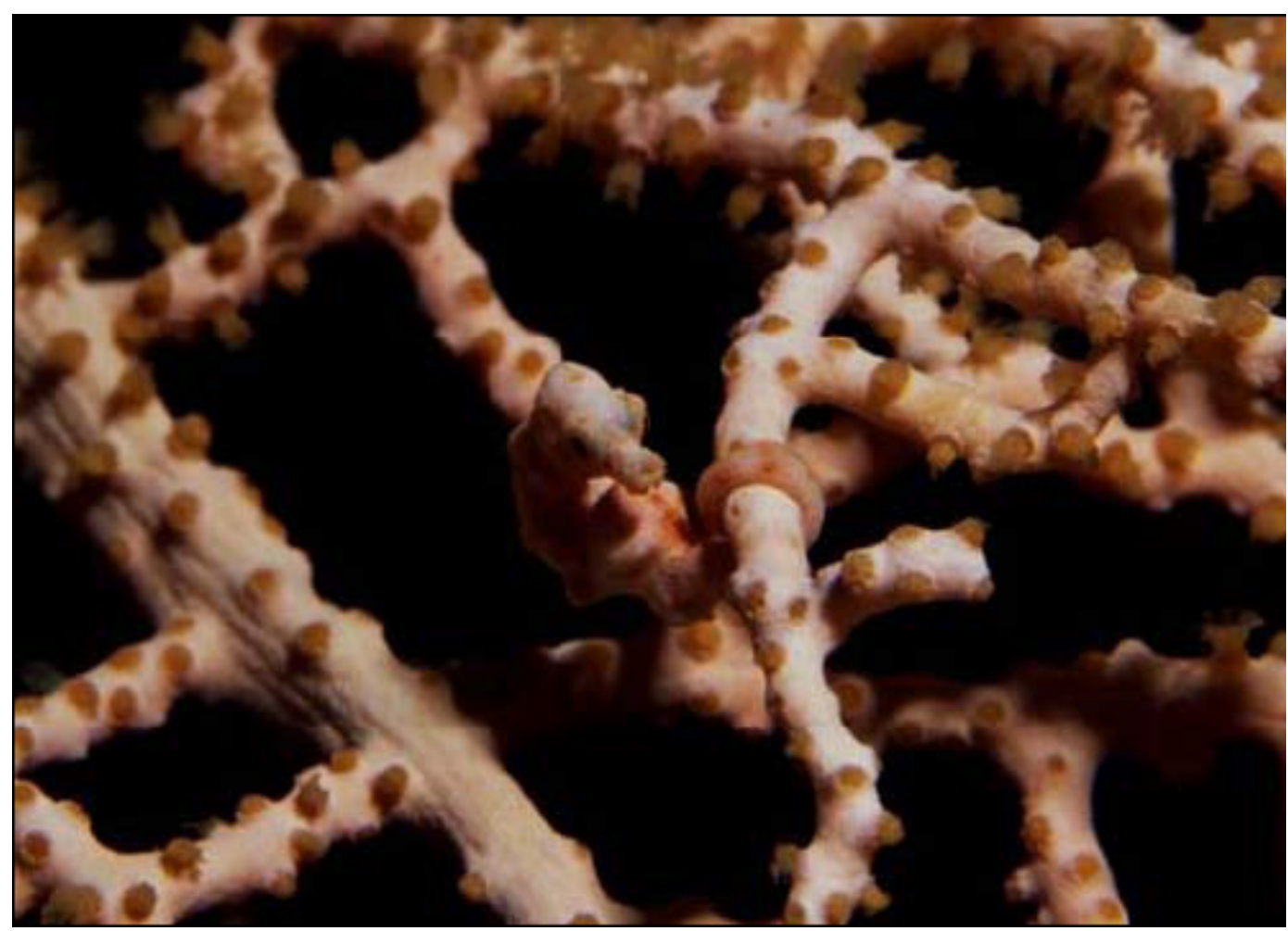

Figure 6a. A pygmy seahorse (Hippocampus bargibanti), clinging to a gorgonian fan in the Western Solomon Islands. These tiny, cryptic animals were "discovered" and became popular with international divers in the late 1990s. Their appeal surely lies in the surprising magnitude of their evolutionary divergence from their much larger and plainer congeners, both in terms of their size and their perfect mimicry of the gorgonians they live on.

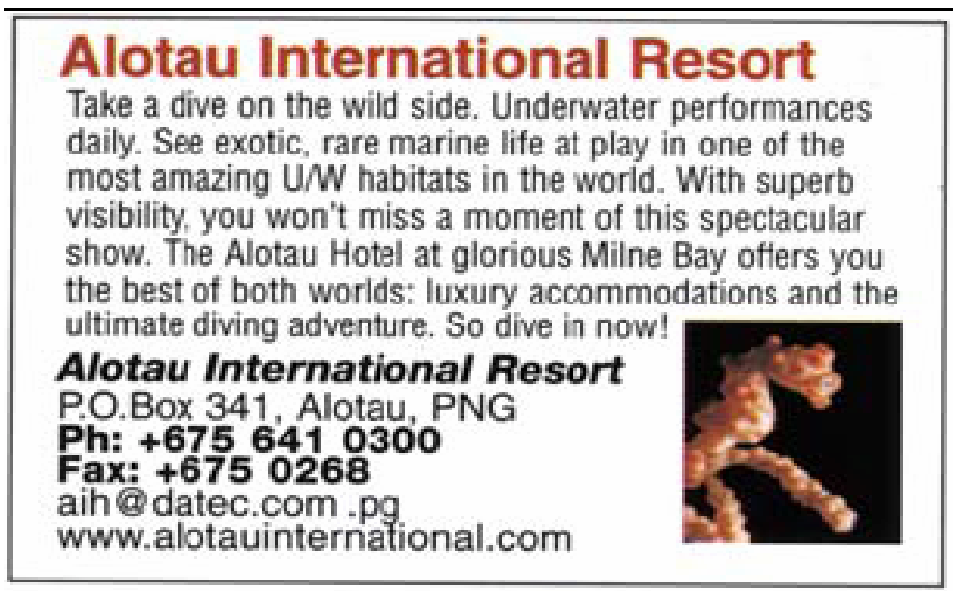

Figure 6b. Advertisement for diving tours in Milne Bay from Ocean Realm Magazine.

The work of Edward Said in his books Orientalism (1978) and Culture and Imperialism (1993) has been acclaimed for its demonstration of the complex ways that colonial aesthetic responses and their expression in [Western/European] literature and art carried assumptions of 
intellectual superiority and racial dominance. Recognition that the cultural underpinnings of environmentalism are often aesthetic and emotional demands that the images used to promote its ideals be scrutinized to expose their implicit political relations. The scientific endorsement of a proprietary concern for global environmental issues, combined with the relative ease of travel enjoyed by people in advanced capitalist economies gives authority and moral justification for transnational actors (environmentalists, development experts, NGO advisors and tourists) to perpetuate their dominance. Indeed, as the problems encountered in establishing ecotourism in places where the local community are unaccustomed to the expectations of transnational 'consumers' of environmental delights illustrate, the tourist enterprise requires smiling servility by the locals. While there is usually an emphasis on 'stakeholder consultation' in the process of developing ecotourist destinations, Pacific islanders who are unaccustomed to tourism are often baffled by the enterprise and unprepared to cater to the level expected by tourists - even those who see themselves 'treading lightly'. In New Ireland in Papua New Guinea we encountered one host at an ecotourism lodge who was puzzled by the fact that her young German male guests expected fish to be provided at each meal when they had been diving on the reef all day. For Papua New Guineans, reef diving is not a leisure activity but a means of providing subsistence and young men are expected to catch fish for themselves.

Janet Chernela has pointed out similar disparities between local desires and the aims of environmentalists setting up ecotourism (J.Chernela 2002) in Silves in the central Brazilian Amazon. She argues that local participation waned as people perceived the privileging of the 'environment' over people to be alien and imperialist: 'A language, based in assumptions of the "rights of nature," and derived from a burgeoning environmental preservation movement, replaced an earlier discourse based in a concept of rights and needs.' (J.Chernela 2002:14) She documents the ways that the environmentalist enterprise gained ground but lost local support, emphasizing the political dominance of the former over the latter: 'The case demonstrates the way in which the dialectic between the state and local constituencies is not only mediated by transnational actors, but, to an extent not recognized by either theorists or actors, it is dominated by them.' (J.Chernela 2002:15).

The analysis by Paige West and James Carrier adds further weight to this argument as they demonstrate the links between ecotourism as an environmentalist or conservationist objective and the fact that generally - but particularly in the Papua New Guinea case study they present ecotourism businesses end up '....subordinating concern for environmental conservation and respect for local communities... to concern for attracting ecotourists and their money.' (2004:491). Martha Honey's comparative study of ecotourism in several countries reaches similar conclusions (M.Honey 1999:220-62). Ecotourism as a form of international consumption, however green, is embedded in the culture and politics of Western consumerism and expansionist economics. The use of nature photography in promoting it provides another instance of 'how green consumerism communicates by cloaking itself in the aura of existing authoritative discourses' (T.Smith 1998:124).

\section{Beautiful photos, prosaic ecologies}

The importance of the aesthetic beauty of these wildernesses is also seen in the photography used by environmentalists, and here the divergence from the ecological rationale again becomes clear. The animals and plants represented in environmentalist brochures and websites, as well as being rare or having some scientific/evolutionary curiosity value, are also usually strikingly coloured and/or anthropomorphically appealing in some way -toucans, anemone-fishes (Figure 7), red-eyed frogs, baby harp seals, all have been abundantly used to symbolise wilderness, regardless of their real ecological importance, or lack of it. WWF's brochure on Forests of New Guinea, part of its "Ecoregions 200" series (D.Olson and E.Dinerstein 2002), leads with a quote from Wallace: "New Guinea contains more strange and new and beautiful objects than any other part of the globe" (WWF 2003). Ironically, Wallace himself expressed annoyance with the misrepresentation of the Amazon by the romantics of his time, as observed by Nancy Stepan: "The problem lay, he said, in "picture drawing travellers who, by only describing the beautiful, the picturesque, and the mmagnificent, would lead a person to believe that nothing else existed under the tropical sun"”. (2001:62). 


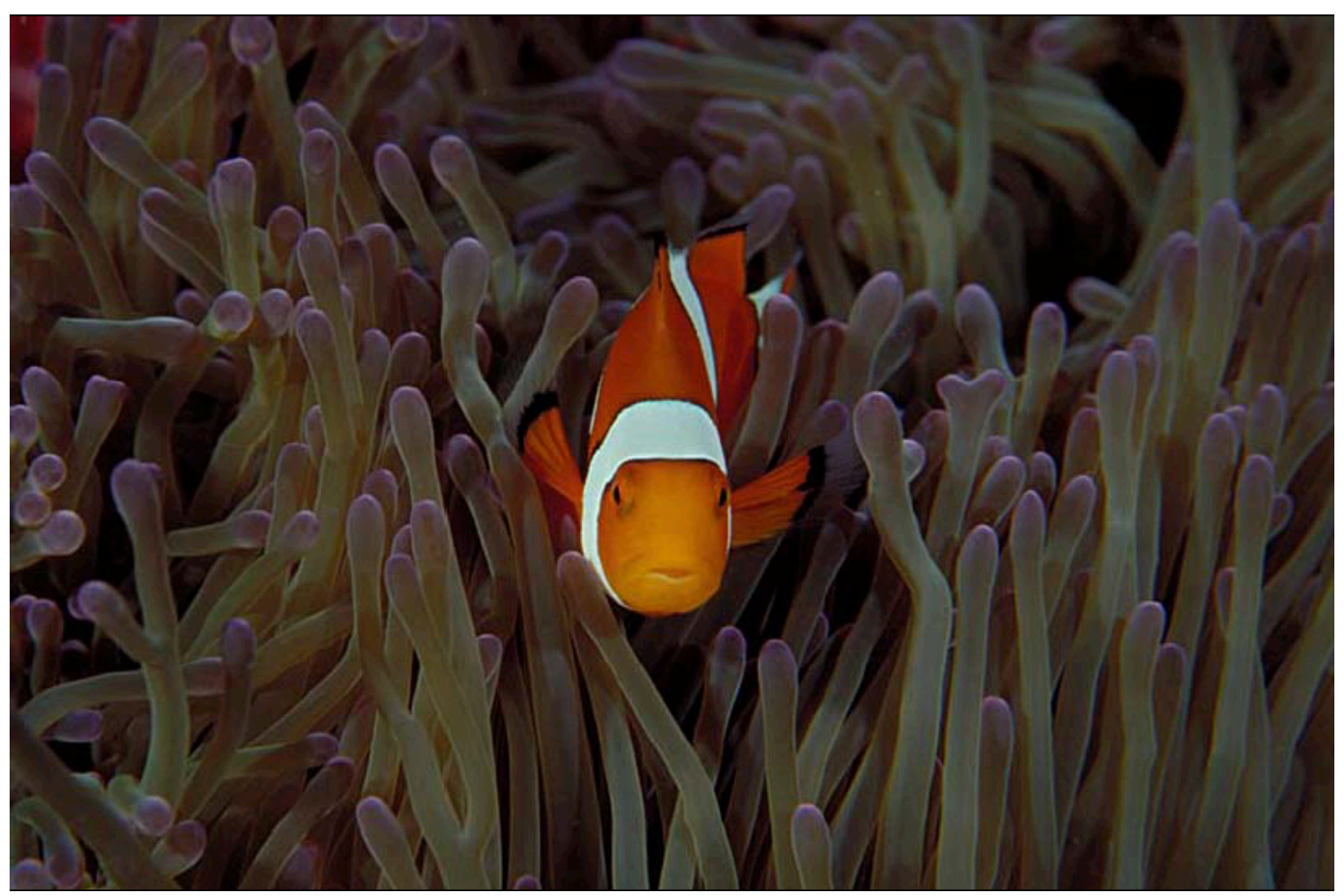

Figure 7. The irresistibly charming Clown Anemonefish (Amphiprion percula) - the model for "Nemo".

The anthropomorphic dimension of the aesthetic appeal is crucial to the evocation of an emotional response that inspires commitment to a specific campaign or more general political activism. Animals that have large (soulful) eyes, appear vulnerable in some way, ${ }^{8}$ sport brilliant colours or can be seen as comical or quaint are far more likely to summon forth the mixture of emotional and aesthetic appreciation that inspires financial generosity. As Kay Milton (2002) has so clearly demonstrated, environmentalist zeal originates in emotional identification, in 'loving Nature', rather than scientific understanding. Nature photography thus presents an essentially unscientific interpretation of ecology and biodiversity. We rarely see photographs of organisms of major ecological importance: soil fungi (D.Lodge et al. 1996; B.Walker 1992), phytoplankton, the symbiotic unicellular algae living within the tissues of corals (G.Mueller-Parker and C.D'Elia 1997), the thousands of drab little insects that perform vital pollination functions (G.Williams et al. 2001). There is also still less than adequate emphasis (if any) on some of the larger environmental NGO's websites and brochures about coral bleaching, which is killing corals all over the developing world, and is driven primarily by profligate fossil fuel consumption in industrialised countries (O.Hoegh-Guldberg 1999; C.Wilkinson 1999; C.Wilkinson et al. 1999; T.Hughes et al. 2003).

Paradoxically, the complex technologies that enable Westerners to visit the Pacific and take photographs are not acknowledged as alien. The whole process of obtaining the photograph - the international travel, the expensive equipment, the profoundly industrial, technologically sophisticated process of manufacturing and processing colour film, prints, or digital images - is all unconsciously excluded in the apprehension of the representation. It is suspended in the interest of indulging in the illusion of being a lone explorer, a single 'eye', while it also embodies the

8. The vulnerability of a species can be conveyed by choosing images of young animals, or more often, of a female with its young, thus drawing on Western traditions of representation that conjure ideas of protection, care and love. 
immense difference in wealth between industrial photographer and pre-industrial landscape (and its inhabitants). The fact that the social context of photography is one of recreation from an industrialized world assists in suspending the economic realities and the economic differences between the photographers and the objects of their gaze.

A good example of the importance of maintaining the fantasy of the non-present photographer in the photographic portrayal of pristine nature can be seen in the convention of minimising "backscatter" in underwater photographs (Figure 8). The presence of backscatter betrays the use of underwater lights, which reminds us of the presence of the technician behind the lens. Backscatter also spoils the expectation of the tropical sea as 'pure' and 'clean' in its clarity, which is indeed a reality for some locations, and on average tropical seas tend to be much clearer than temperate ones. However the attempt to deny the presence of particles in the water, even on reefs, many of which grow in naturally turbid, nutrient-rich waters (B.Hatcher 1997), utterly obscures the complexity and variety of coral reef ecosystems. Reef waters can in many places be a living soup, swarming with the microscopic larvae of a myriad species of reef fauna, immense numbers and diversity of tiny crustaceans and other types of plankton, as well as all sorts of abiotic particles, gobs of mucous produced by corals, and "marine snow" which is an agglomerate of sediment, microbes and mucous (T.Kiorboe 2003). Many of these aesthetically annoying specs are vitally important food sources for the pretty reef fish that are so often photographed, as well as many benthic organisms (N.Polunin 2002, K.Fabricius and M.Dommisse 2000).

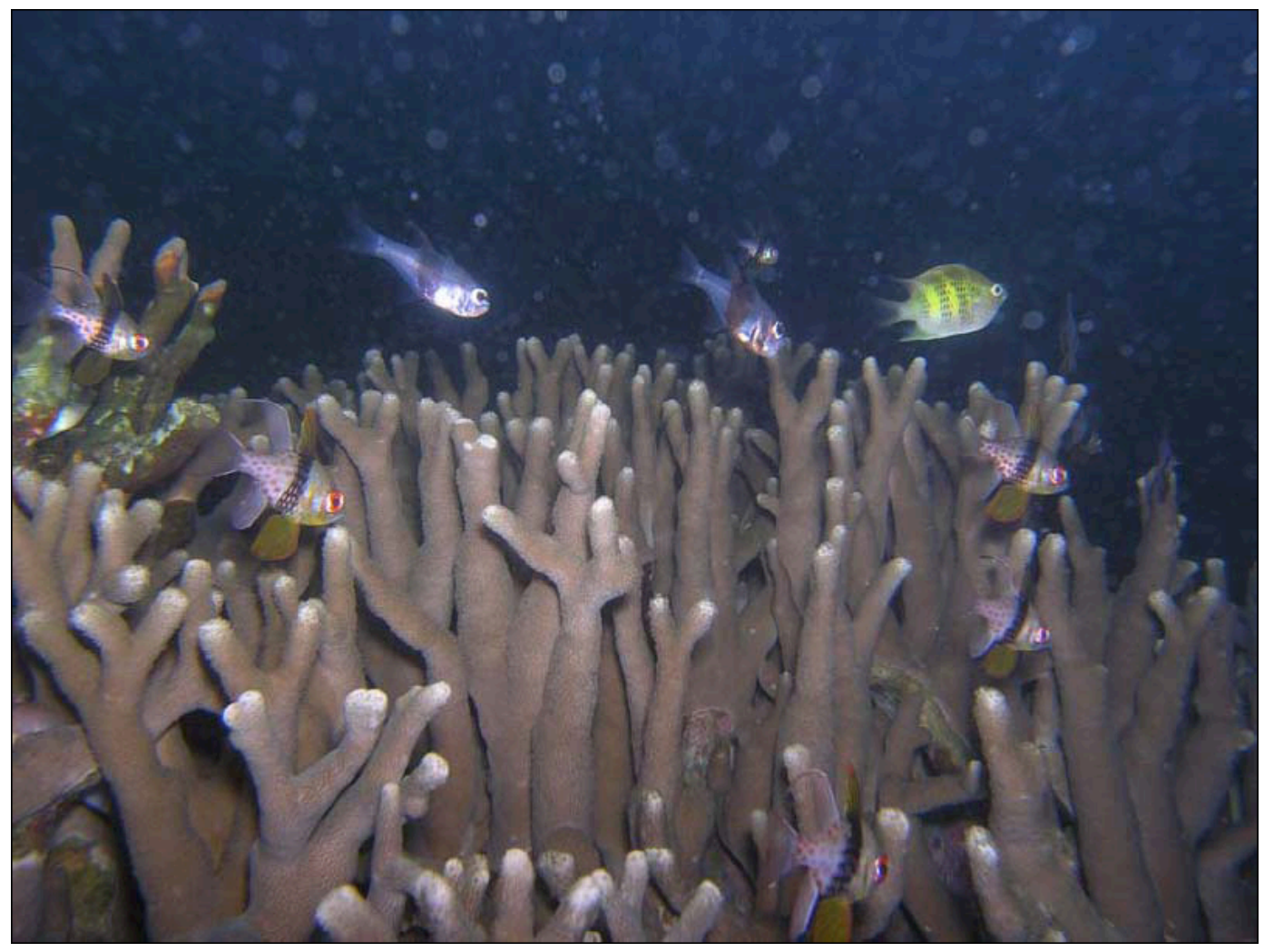

Figure 8. An illustration of "backscatter" in an underwater photograph. This "problem" can be minimised by mounting underwater flashes on long arms off to the side of the camera. Most underwater photographs, particularly those featuring dramatically colourful subjects in the foreground, are artificially lit. If artificial lighting is carefully controlled, and subtly balanced with ambient light (e.g. Figure 1), it can go largely un-noticed to the un-trained eye.

The desired illusion at all times with underwater photography is that of the naturally lit subject, which of course becomes increasingly difficult below ten metres because of the rapid fall- 
off of light intensity, the increasing dominance of blue wavelengths, and the constraints of colour film speed (or digital sensor sensitivities) and lens apertures.

There are also a host of other "rules" for what constitutes a good wildlife photo - eyes must be sharp, well composed; no clutter in the frame (especially not human clutter like fences or rubbish); the animal must be looking natural (not stressed or trying to escape) and lighting must look natural. While it is acceptable to 'catch' an image of an animal running or hiding, it will only be published if the head is visible. The fact that most animals are glimpsed fleetingly in dense green foliage or darting between coral and rocks underwater means that the studio and the tank are often used by professional photographers. Indeed Stephen Dalton, a brilliant and multiple prizewinning photographer, specialises in high-tech, often studio-based photography that captures animal behaviours that are essentially impossible to capture in the wild. He goes to great lengths however to convey the illusion of the animal being situated in its natural environment (S. Dalton et al. 1990, G. Harrison 1995:52-56). Wildlife photography is recognised as both an aesthetic and a technical feat.

\section{Indigenous people - Malthusian Menace or Ecological Nobility?}

In areas of the world such as the Brazilian rainforests or the islands and reefs of Melanesia, humans are in many respects seen as vandals or potential destroyers of "globally important" biodiversity. In his critique of 'fundamentalist ecology', Jeffrey Schantz has pointed out that their essentialist discourses 'have tended to construct 'humanity' as a bloc, undifferentiated by power, in which a universalistic human species itself is held responsible for biospheric destruction.' (2003:148). Sometimes the indigenous population are relieved of the guilt as the accusers of 'humanity' embrace the ideal of the 'noble savage' who is a 'natural' custodian of the environment (see below). These same ideologies routinely disregard the fact that local inhabitants might be very proprietorial about their land and sea resources and deeply resent the idea that foreigners have any right to unilaterally declare their land, fish, animals or plants in need of 'conservation' or to limit their economic activities. The desire to proclaim whole areas of rainforest or coral reefs as 'national parks' often ignores the populations for whom the forests or reefs provide their subsistence, their livelihood. Sue Wheat (2002:28) documents state-sponsored evictions of large numbers of people in Philippines, Bangladesh, Indonesia, Brazil and Ecuador, to make way for large ecotourism development projects. Jeevan Vasagar (2004:29) describes recent examples of "fortress conservation" in Kenya, in which Maasai farmers have been forced off their land by game park operators who claim that the Masai are destroying the landscape by overgrazing - claims which Daniel Brockington and Katherine Homewood (1996: 96) found to be without substance in similar conflicts in several African countries.

But contradictory stances are taken up in defence of Nature. Opposing constructions of local inhabitants can also hold. Sometimes, when their existence is acknowledged, they are viewed as part of the landscape - embedded, or living in complementary harmony with 'Nature'. image, while it has been most commonly used to portray indigenous people as heroic victims of predatory resource extraction corporations (P.Brosius 1999; L.Vivanco 2002), also uncritically endorses ecotourism as the ideal alternative form of development.

This imagined harmonious symbiosis ignores historical details such as the fact that often indigenous people have been forced out of the areas they once occupied - and currently live on the margins of land used for plantations, farming, logging and mining (Indigenous Australians being a prime case) and in most instances in Melanesia, the low population densities allowed types of land use that did not require attention to conservation principles (R.Bulmer 1982). Human depredations were simply not of a scale that jeopardised biodiversity, and in many cases have probably enhanced it (H.Brookfield and C.Padoch 1994; W.Clarke and R.Thaman 1997). However, in a fascinating recent study based in the Western Solomon Islands, a combination of floristic, oral history and archaeological analyses have been used to show that pre-colonial agroforestry systems have generated conspicuous large patches of low-diversity forest (T.Bayliss-Smith et al. 2003). Collectively these studies, like those of Fairhead and Leach (1996) in West Africa, call for a much

9. "Zoofication" is a term coined by M. Mowforth and I. Munt (1998: 273-76, as cited by P.West and J.Carrier, 2003:485) for this process. 
more sophisticated appraisal of pre-industrial human-environment relationships than the essentialized images presented by many environmentalist groups.

In the article "Endangered Forest, Endangered People" Peter Brosius examines the rhetoric of the (European) environmentalists and their representations of the local Penan people in their campaign against logging companies. He reveals the ways that environmentalists transform ethnographic descriptions into "... a form of ecological etherealism that is derived entirely from the Western romantic tradition..." (1997:59) thus turning the pragmatic management of subsistence plants employed by the Penan into "..a sacred obligation to bequeath to the following generations a healthy forest fully capable of providing life to its human inhabitants." Similar assumptions inform the heady blend of Nature and 'spiritual beliefs' that permeates some of the more extreme environmentalist writings (J.Lovelock 1979; F.Besthorn and D.McMillen 2002; M.Haigh 2002).

\section{Conclusion}

The emphasis on global environmental responsibility in current Western discourses derives not only from scientific awareness of species loss, the effects of pollution and the role of humans in environmental transformation, but from the political dominance based on the industrial and technological advantages that the 'West' has gained. Bernard Smith's recognition of the interweaving of aesthetics, European Romanticism, scientific curiosity and the development of scientific theories of evolution in the representation of the Pacific has its contemporary counterpart. The construction of the region as an area of 'unspoiled' beauty has in many ways continued to shape the 'European Vision'. Now presented in film and photograph, the Pacific remains an imagined 'Paradise'. The exploitation of the natural resources of the Pacific region - its minerals, fisheries, timber, fertile soils and the labour of its people - that began two centuries ago (and inspired its 'exploration') has facilitated the maintenance of political and economic power. Part of that political dominance requires that the region be seen as a "natural" world, unaffected by the forces that have destroyed so much in industrialised countries. Maintenance of this illusion means that many transformative interventions are ignored, censored or denied: the atomic testing on its atolls, the mining of guano that has left several islands wastelands, the pollution of rivers and reefs by mining operators, the destruction of forests for log exports or plantations, and the increasingly devastating impacts of global warming. In the late 20 th and early 21 st centuries, the triumph of the capitalist endeavours that began the European transformation of the Pacific environment 200 years ago have generated leisure and the capacity for travel. The romanticism has transmuted and has new modes of visual representation that inspire new forms of consumption. The imbrication of scientific, aesthetic and commodifying representations is vividly represented in the photography and in the construction of Pacific islands as destinations for jaded Westerners who continue to consume its resources and to subjugate the interests, desires and in some cases even the existence of Pacific people.

\section{References Cited}

Andre, J., E. Gyuris and I. R. Lawler.

"Comparison of the diets of sympatric dugongs and green turtles on the Orman Reefs, Torres Strait, Australia." Wildlife Research 32 (2005): 53-62.

Bayliss-Smith, Tim, Edvard Hviding, and Tim Whitmore.

"Rainforest Composition and Histories of Human Disturbance in Solomon Islands." Ambio 32, no. 5 (2003): 346-52.

Berlin, B., D. E. Breedlove and P. H. Raven.

"General principles of classification and nomenclature in folk biology." American Anthropologist 75 (1973): 214-242.

Besthorn, F. H., and D. P. McMillen.

"The Oppression of Women and Nature: Ecofeminism as a Framework for an Expanded Ecological Social Work." Families in Society-the Journal of Contemporary Human Services 83, no. 3 (2002): 221-32. 
Brockington, Daniel, and Katherine Homewood.

"Wildlife, Pastoralists and Science: Debates Concerning Mkomazi Game Reserve, Tanzania." In The Lie of the Land: Challenging Received Wisdom on the African Environment, edited by Melissa Leach and Robin Mearns, 91-104. London: The International African Institute, 1996.

Brookfield, H.C., and C. Padoch.

"Appreciating Agrodiversity: A Look at the Dynamism and Diversity of Indigenous Farming Practices." Environment 36, no. 5 (1994): 5-11, 37-45.

Brosius, J.P.

"Endangered Forest, Endangered People: Environmentalist Representations of Indigenous Knowledge." Human Ecology 25, no. 1 (1997): 47-69.

Bulmer, Ralph N. H.

"Traditional Conservation Practices in Papua New Guinea." In Traditional Conservation in Papua New Guinea: Implications for Today, edited by Louise Morauta, John Pernetta and William Heaney, 59-77. Boroko, PNG: Institute of Applied Social and Economic Research, 1982.

Ceballos Lascurain, $\mathrm{H}$.

Tourism, Ecotourism and Protected Areas. Gland, IUCN. 1996.

Chernela, Janet.

"Ngo-Ization Amazon Style: Democracy, Social Action, and Ngos in the Central Brazilian Amazon." Paper presented at the Annual Meetings of the American Anthropological Association, Washington D.C. 2002.

Clarke, W.C.

"Learning from Ngirapo: Indigenous Knowledge and Sustainable Agricultural Development." In The Margin Fades: Geographical Itineraries in a World of Islands, edited by E. Waddell and P.D. Nunn, 231-66. Suva: Institute of Pacific Studies, 1993.

Clarke, W.C., and R. Thaman.

"Incremental Agroforestry: Enriching Pacific Landscapes." The Contemporary Pacific 9, no. 1 (1997): 12-148.

Crowder, L.

"Leatherback's survival will depend on an international effort." Nature 405 (6789) (2000): $881-881$.

Curry, G.

"Markets, social embeddedness and precapitalist societies: the case of village trade stores in Papua New Guinea." Geoforum 30 (1999): 285-298.

Dalton, Stephen, George Bernard, and Andrew Mitchell.

Vanishing Paradise. London: Century Hutchinson, 1990.

Dulvy, N. K., R. P. Freckleton, N. V. C. Polunin.

"Coral reef cascades and the indirect effects of predator removal by exploitation." Ecology Letters 7, no. 5 (2004): 410-416.

Ellis, J.-A.

Race for the Rainforest II. Applying lessons learned from the Bismark-Ramu Integrated Conservation and Development Initiative in Papua New Guinea, Waigani, PNG: PNG Biodiversity Conservation and Resource Management Programme. 1997.

Ernst, Manfred.

Winds of Change: Rapidly Growing Religious Groups in the Pacific Islands. Suva: Pacific Conference of Churches, 1994.

Estes, J. A. and D. O. Duggins.

"Sea Otters and Kelp Forests in Alaska - Generality and Variation in a Community Ecological Paradigm." Ecological Monographs 65, no. 1 (1995): 75-100.

Estes, J. A., M. T. Tinker, T. M. Williams, D. F. Doak.

"Killer whale predation on sea otters linking oceanic and nearshore ecosystems." Science 282(5388) (1998): 473-476.

Fabricius, K. E., and M. Dommisse.

"Depletion of Suspended Particulate Matter over Coastal Reef Communities Dominated by Zooxanthellate Soft Corals." Marine Ecology-Progress Series 196 (2000): 157-67. 
Fairhead, J., and M. Leach.

"Enriching Landscapes: Social History and the Management of Transition Ecology in Guinea's Forest-Savanna Mosaic." University of London/University of Sussex, 1994.

Fairhead, James, and Melissa Leach.

Misreading the African Landscape: Society and Ecology in a Forest-Savanna Mosaic, African Studies Series 90. Cambridge: Cambridge University Press, 1996.

Filer, Colin. . "The Nature Lords." Times Literary Supplement 5th May, (2000): 3-4.

Loggers, Donors and Resource Owners. Edited by James Mayers, Policy That Works for Forests and People Series No. 2. Port Moresby and London: Papua New Guinea National Research Institute and International Institute for Environment and Development, 1998.

Foale, Simon.

"What's in a name? An analysis of the West Nggela (Solomon Islands) fish taxonomy." SPC Traditional Marine Resource Management and Knowledge Information Bulletin 9 (1998): 2-19.

Foale, Simon

"'Where's Our Development?' Landowner Aspirations and Environmentalist Agendas in Western Solomon Islands." The Asia Pacific Journal of Anthropology 2, no. 2 (2001): 44-67.

Gerritsen, R. and M. Macintyre.

"Dilemmas of distribution: the Misima goldmine, Papua New Guinea." In Mining and Indigenous Peoples in Australasia, Edited by J. Connell and R. Howitt. 35-53, Sydney, Sydney University Press, 1991.

Ghilarov, Alexej.

"What Does 'Biodiversity' Really Mean: Scientific Problem or Convenient Myth?" Trends in Ecology and Evolution 11, no. 7 (1996): 304-06.

Goodland, R. J. A., E. O. A. Asibey, J. C. Post, and M. B. Dyson.

"Tropical Moist Forest Management - the Urgency of Transition to Sustainability." Environmental Conservation 17, no. 4 (1990): 303-18.

Haigh, M. J.

"Land Reclamation and Deep Ecology: In Search of a More Meaningful Physical Geography." Area 34, no. 3 (2002): 242-52.

Harrison, G.H., ed.

Magnificent Moments: The World's Greatest Wildlife Photographs. Minocqua Wisconsin: Willow Creek Press, 1995.

Hatcher, B. G.

"Coral Reef Ecosystems: How Much Greater Is the Whole Than the Sum of the Parts?" Coral Reefs 16 Suppl. (1997): S77-S91.

Hitchcock, Robert K.

"Cultural, Economic and Environmental Impacts of Tourism among Kalahari Bushmen." In Tourism and Culture: An Applied Perspective, edited by Erve Chambers, 93-128. New York: State University of New York Press, 1997.

Hoegh-Guldberg, O.

"Climate Change, Coral Bleaching and the Future of the World's Coral Reefs [Review]." Marine \& Freshwater Research 50, no. 8 (1999): 839-66.

Honan, M. and D. Harcombe.

Solomon Islands. Melbourne, Lonely Planet, 1997

Hughes, $\mathrm{H}$.

"Aid Has Failed the Pacific." Issue Analysis - Journal of the Centre for Independent Studies Hughes, $\mathrm{H}$. no. 33 (2003): 1-32.

"Can Papua New Guinea Come Back From the Brink?" Issue Analysis - Journal of the Centre for Independent Studies no. 49 (2004): 1-12.

Hunt, E., J.-B. Carillet, K. Galbraith, R. Jone, N. Keller, J. Lyon, R. McKinnon, D. O'Byrne, L. Pinhero and T. Wheeler.

South Pacific: Polynesia, Melanesia and Micronesia. Melbourne, Lonely Planet, 2000. 
Hviding, Edvard

"Contested Rainforests, NGOs, and Projects of Desire in Solomon Islands." Int Social Science $J$ 55, no. 4 (2003): 539-54.

Hviding, Edvard, and Tim Bayliss-Smith.

Islands of Rainforest: Agroforestry, Logging and Ecotourism in Solomon Islands. Aldershot: Ashgate, 2000.

Jackson, J. B. C., M. X. Kirby, W. H. Berger, K. A. Bjorndal, L. W. Botsford, B. J. Bourque, R. H. Bradbury, R. Cooke, J. Erlandson, J. A. Estes, T. P. Hughes, S. Kidwell, C. B. Lange, H. S. Lenihan, J. M. Pandolfi, C. H. Peterson, R. S. Steneck, M. J. Tegner, and R. R. Warner.

"Historical Overfishing and the Recent Collapse of Coastal Ecosystems [Review]." Science 293, no. 5530 (2001): 629-38.

Kareiva, P. and M. Marvier.

“Conserving biodiversity coldspots", American Scientist 91, no. 4 (2003): 344-351.

Kawasaki, H., M. Sano, and T. Shibuno.

"The Relationship between Habitat Physical Complexity and Recruitment of the Coral Reef Damselfish, Pomacentrus Amboinensis: An Experimental Study Using Small-Scale Artificial Reefs." Ichthyological Research 50, no. 1 (2003): 73-77.

Kiorboe, T.

"Marine Snow Microbial Communities: Scaling of Abundances with Aggregate Size." Aquatic Microbial Ecology 33, no. 1 (2003): 67-75.

Knowlton, N.

"Thresholds and multiple stable states in coral reef community dynamics." American Zoologist 32(1992): 674-682.

Kucklick, Henrietta.

The Savage Within: The Social History of British Anthropology, 1885- 1945. Cambridge: Cambridge University Press, 1991.

Leon, Y. M. and K. A. Bjorndal.

"Selective feeding in the hawksbill turtle, an important predator in coral reef ecosystems." Marine Ecology-Progress Series 245 (2002): 249-258.

Levantis, T.

Papua New Guinea: employment, wages and economic development. Canberra, Asia Pacific Press, 2000.

Lodge, D. Jean, David L. Hawksworth, and Barbara J. Ritchie.

"Microbial Diversity and Tropical Forest Functioning." In Biodiversity and Ecosystem Processes in Tropical Forests, edited by Gordon H. Orians, Rodolpho Dirzo and J. Hall Cushman, 69-100. Berlin: Springer, 1996.

Lonely Planet.

One Planet: See it for yourself. Melbourne: Lonely Planet Publications, 2003.

Loreau, M., S. Naeem, P. Inchausti, J. Bengtsson, J. P. Grime, A. Hector, D. U. Hooper, M. A. Huston, D. Raffaelli, B. Schmid, D. Tilman, and D. A. Wardle.

"Ecology - Biodiversity and Ecosystem Functioning: Current Knowledge and Future Challenges." Science 294, no. 5543 (2001): 804-08.

Lovelock, J.E.

Gaia: A New Look at Life on Earth. Oxford: Oxford University Press, 1979.

Macintyre, Martha, and Simon Foale.

"Global Imperatives and Local Desires: Competing Economic and Environmental Interests in Melanesian Communities." In Globalisation and Culture Change in the Pacific Islands, edited by Victoria Lockwood, 149-64. Upper Saddle River, New Jersey: Pearson Prentice Hall, 2004a.

Macintyre, Martha, and Simon Foale.

"Politicised Ecology: Local Responses to Mining in Papua New Guinea." Oceania 74, no. 3 (2004b): 231-51.

McCook, L. J.

"Macroalgae, nutrients, and phase shifts on coral reefs: scientific issues and management Milton, $\mathrm{K}$. consequences for the Great Barrier Reef." Coral Reefs 18, no. 4 (1999): 357-367.

Loving Nature: Towards an Ecology of Emotion. London: Routledge, 2002. 
Simon Foale and Martha Mcintyre

Mueller-Parker, Gisele, and D'Elia Christopher F.

"Interactions between Corals and Their Symbiotic Algae." In Life and Death of Coral Reefs, edited by C. Birkeland, 96-113. New York: Chapman and Hall, 1997.

Myers, $\mathrm{N}$.

"Biodiversity and the precautionary principle." Ambio 22, no. 2-3 (1993): 74-79.

Myers, N., R. A. Mittermeier, C. G. Mittermeier, G. A. B. da Fonseca, and J. Kent.

"Biodiversity Hotspots for Conservation Priorities." Nature 403, no. 6772 (2000): 853-58.

Olson, D. M., and E. Dinerstein.

"The Global 200: Priority Ecoregions for Global Conservation." Annals of the Missouri Botanical Garden 89, no. 2 (2002): 199-224.

Orians, Gordon H., Rodolpho Dirzo, and J. Hall Cushman, eds.

Biodiversity and Ecosystem Processes in Tropical Forests. Edited by M.M. Caldwell, G. Heldmaier, O.L. Lange, H.A. Mooney, E.-D. Schulze and U. Sommer. 1 vols. Vol. 122, Ecological Studies. Berlin: Springer, 1996.

Pawley, Andrew.

"Were turtles 'Fish' in Proto Oceanic? Notes on the comparative study of taxonomies in Oceanic Languages." Leo Pasifika. Proceedings of the Fourth International Conference on Oceanic Linguistics. S. R. Fisher and S. W.B. 1-43. Aukland: The Institute of Polynesian Languages and Literatures, 2000.

Polunin, Nicholas V.C., and J.K. Pinnegar.

"Trophic Ecology and the Structure of Marine Food Webs." In Handbook of Fish Biology and Fisheries, edited by Paul J.B. Hart and John D. Reynolds, 301-20. London: Blackwell, 2002.

Randall, J. E., G. R. Allen and R. C. Steene.

Fishes of the Great Barrier Reef and Coral Sea, Bathurst: Crawford House Press, 1990.

Roberts, C.

"Settlement and Beyond: Population Regulation and Community Structure of Reef Fishes." In Reef Fisheries, edited by N.V.C. Polunin and C. Roberts, 85-112. London: Chapman and Hall, 1996.

Roberts, C.

"Trouble Ahead for Coral Reefs." Marine Pollution Bulletin 26, no. 12 (1993): 709-10.

"Effects of Fishing on the Ecosystem Structure of Coral Reefs." Conservation Biology 9 (1995): 988-95.

Said, Edward.

Culture and Imperialism. London: Vintage, 1993. . Orientalism. London: Routledge and Kegan Paul, 1978.

Seppänen, Janne and Esa Väliverronen.

Visualising Biodiversity: The Role of Photographs in Environmental Discourse, Science as Culture 12, no. 1 (2003): 59-85.

Shantz, Jeffrey

"Scarcity and the Emergence of Fundamentalist Ecology." Critique of Anthropology 23, no. 2 (2003): 144-54.

Smith, Bernard.

European Vision and the South Pacific. New York: Yale University Press, 1959.

Sontag, Susan

On Photography. New York, Farrar, Straus and Giroux, 1977.

Stepan, Nancy Leys.

Picturing Tropical Nature. New York: Cornell University Press, 2001.

Thomas, Nicholas.

The Voyages of Captain Cook. London: Penguin, 2003.

Van Helden, Flip.

Between Cash and Conviction. The Social Context of the Bismark-Ramu Integrated Conservation and Development Project. Port Moresby: National Research Institute, 1998.

— . "Through the Thicket: Disentangling the Social Dynamics of an Integrated Conservation and Development Project on Mainland Papua New Guinea." Ph.D., Wageningen University, 2001.

Vasagar, Jeevan.

"Give Us Back Our Land, Say Masai." Guardian Weekly, August 13-19 2004, 29. 
Green Fantasies

Veech, J. A.

"Incorporating Socioeconomic Factors into the Analysis of Biodiversity Hotspots." Applied Geography 23, no. 1 (2003): 73-88.

Vivanco, L. A.

"Seeing Green: Knowing and Saving the Environment on Film." American Anthropologist 104, no. 4 (2002): 1195-204.

Walker B.

"Biodiversity and Ecological Redundancy". Conservation Biology 6: 18-23, 1992.

Wheat, Sue.

"Visiting Disaster." The Guardian Weekly, June 20, 2002: 28.

Wild, C., M. Huettel, A. Klueter, S. G. Kremb, M. Y. M. Rasheed and B. B. Jorgensen.

Coral mucus functions as an energy carrier and particle trap in the reef ecosystem, Nature (London) 428 (2004) 66-70.

Wilkinson, C., O. Linden, H. Cesar, G. Hodgson, J. Rubens, and A. E. Strong.

"Ecological and Socioeconomic Impacts of 1998 Coral Mortality in the Indian Ocean: An ENSO Impact and a Warning of Future Change?" Ambio 28, no. 2 (1999): 188-96.

Wilkinson, C. R.

"Global and Local Threats to Coral Reef Functioning and Existence: Review and Predictions." Marine and Freshwater Research 50, no. 8 (1999): 867-78.

Williams, G. A., P. Adam, and L. A. Mound.

"Thrips (Thysanoptera) Pollination in Australian Subtropical Rainforests, with Particular Reference to Pollination of Wilkiea Huegeliana (Monimiaceae)." Journal of Natural History 35, no. 1 (2001): 1-21.

Wilson, E.O.

The Diversity of Life. London: Penguin, 1992.

WWF.

"Pacific Ecoregion in Action: Forests of New Guinea." Suva: World Wide Fund for Nature South Pacific Programme, 2003.

Yamaguchi, Masashi.

"Green Snail." In Nearshore Marine Resources of the South Pacific, edited by Andrew Wright and Lance Hill, 497-511. Suva: Institute of Pacific Studies, Forum Fisheries Agency, International Centre for Ocean Development, 1993. 
Simon Foale and Martha Mcintyre

\begin{abstract}
Photography is a powerful tool for persuading donors to support conservation programs in the Pacific, but it frequently distorts the ecological concepts from which their legitimacy is derived. In this paper we argue that the images of charismatic wildlife used to portray the Pacific as a "pristine wilderness" of rainforest and reef, betray the hegemonic ideology underpinning both biodiversity conservation and its related ecotourism development projects.
\end{abstract}

Key Words: Biodiversity, Pacific, photography, environmentalism

\title{
Résumé
}

La photographie est un outil puissant pour persuader les bailleurs de fonds à soutenir les programmes de conservation dans la Pacifique, mais souvent elle présente mal les idées écologiques d'où sa légitimité dérive. Dans cet article nous proposons que les images charismatiques des faunes utilisés pour présenter la Pacifique comme une "region sauvage et pristine" de forêt et de ris, ne font que refléter l'idéologie hégémonique qui soutient la conservation de la biodiversité et les projets d'aménagement d'ecotourisme.

Mots clefs : la biodiversité, la Pacifique, la photographie, l'environnementalisme.

\section{Resumen,}

La fotografía es una herramienta de gran alcance para persuadir a donantes apoyar programas de la conservación en el Pacífico, pero tuerce con frecuencia los conceptos ecológicos de los cuales se deriva su legitimidad. En este papel discutimos que las imágenes de la fauna carismática usadas para retratar el Pacífico como "yermo prístino" del bosques tropicales lluevosos y de arrecifes de coral, traicionen la conservación de apoyo de la biodiversidad de la ideología hegemonic y sus proyectos relacionados del desarrollo del ecotourism.

Palabras claves: Biodiversidad, el Pacífico, fotografía, environmentalism 